\title{
Cloning of the Soul and Reproduction of the Self through Space and Time with Reference to Literature and Translation
}

\section{Prof. Yasser Aman}

\begin{abstract}
Texts' souls have been cloned and their selves reproduced. History of ideas have been passed from generation to generation and translated from one language to another. In each generation, a text represents an author's ideas that are enclosed in a time-space frame. Representation of ideas may take another turn with the death of the author: soul cloning or self-reproduction. Between cloning and reproduction, translation stands as a reconstruction of memory and a channel through which a rebirth of texts, loaded with ideas, concepts, traditions, and cultural practices, are transmitted. Between the source text and the target, text a third text lingers in space and time waiting to be reborn. I argue that space and time play an important role in the emergence of the ever-evolving third text giving it an identity based on Mikhail Bakhtin's chronotope. The third text is constructed by the readers' interpretations rather than the authors' intentions as Roland Barthes maintains. The author is dead, the reader is there to interpret and the text floats, mutates and is reshaped through time and space.
\end{abstract}

\section{Keywords}

Cloning, Reproduction, Death of the Author, Bakhtin's Chronotope, Literature, Translation 



\section{Cloning of the Soul and Reproduction of the Self through Space and Time with Reference to Literature and Translation}

\section{The Death of the Author}

In 1967 Roland Barthes wrote an essay titled "The Death of the Author". Barthes intended to shift the idea that an explanation of a text depends on wider cultural codes and that the author is the creator of the text. (Barthes 146). The identity of the writer is lost in literature although it has been a custom that the work of art depends on its explanation on the writer. Many writers, such as Mallarme and Valery, belittled the authority of the writer (Bathes 146). From a linguistic point of view, the author is no more than the "I" that writes. Once produced, the text is completely separated from the author who preexists the text. The modern writer/scriptor is born with the text. Therefore, the text is fed from the enormous dictionary of life:

the scriptor no longer bears within him passions, humours, feelings, impressions, but rather this immense dictionary from which he draws a writing that can know no halt: life never does more than imitate the book, and the book itself is only a tissue of signs, an imitation that is lost, infinitely deferred. (Barthes 147)

It is the reader who represents the space and time for the text, who interacts with the text and with every experience of reading the text takes a different turn and assumes a new identity fed by the reader's life experiences. Barthes concludes that "we know that to give writing its future, it is necessary to overthrow the myth: the birth of the reader must be at the cost of the death of the Author" (148). Therefore, the text indicates the birth of the reader as well as the death of the author. However, for Bakhtin the author's image created by the reader/listener is important "if this image is deep and truthful, it can help the listener or reader more correctly and profoundly to understand the work of a given author" (257).

\section{Bakhtin's Chronotope}

In his book The Dialogic Imagination, in the third essay titled "Forms of Time and of the Chronotope in the Novel", Bakhtin gives a detailed account of the importance of the chronotpe to the development of the novel. Time and space cut through processes of cloning and reproduction: time may differ and space is the same or vice versa. A chronotope, time-space or time-place, shapes the meaning because it is where all knots of 
the narrative come and unite. It serves as a frame for events; however, it cannot be located. It stresses the inseparability of space and time and materializes time in space:

In the literary artistic chronotope, spatial and temporal indicators are fused into one carefully thought-out, concrete whole. Time, as it were, thickens, takes on flesh, becomes artistically visible; likewise, space becomes charged and responsive to the movements of time, plot, and history. This intersection of axes and fusion of indicators characterizes the artistic chronotope. (Bakhtin 84)

The concept of adventure-time in the Greek romance, the adventure novels or the first type of ancient novels as Bakhtin calls it, shows no change as it is "an extratemporal hiatus that appears between two moments of a real-time sequence, in this case, one that is biographical" (91). This type of time can be best described by "suddenly" and "at just that moment" (92) which are remarkable of "random contingencies" (94). The second type, adventure novel of everyday life, shows how the idea of metamorphosis as development is complicatedly unraveled; therefore, "the types of temporal sequences that develop out of it are extremely varied" (113). This type of time is "a time of exceptional and unusual events, events determined by chance, which, moreover, manifest themselves in fortuitous encounters (temporal junctures) and fortuitous nonencounters (temporal disjunctions)" (116). The third type which is found in ancient biographical and autobiographical forms is "a new type of biographical time and a human image constructed to new specifications, that of an individual who passes through the course of a whole life" (130).

Discussing the problem of historical inversion and the folkloric chronotope, Bakhtin maintains that "if taken outside its relationship to past and future, the present loses its integrity, breaks down into isolated phenomena and objects, making of them a mere abstract conglomeration" (146). The chivalric adventure romance is different from the Greek romance but closer to the epic and its chronotope is "a miraculous world in adventure-time"(154). In the chivalric romance time is miraculous as "hours are dragged out, days are compressed into moments, it becomes possible to bewitch time itself" (154). In the miraculous world, the chronotope shows a subjective playing with time as well as space.

The temporal and spatial nature of time, a positive feature of folkloric time as Bakhtin maintains, shows itself when it is connected to the earth, especially agriculturally:

The seasons of the year, ages, nights and days (and their subcategories), copulation (marriage), pregnancy, ripening, old age and death: all these categorical images serve equally well to plot the course of an individual life and the life of nature (in its agricultural aspect). All these images are profoundly chronotopic. Time here is sunk deeply in the earth, implanted in it and ripening in it. Time in its course binds together the earth and the laboring hand of man; man creates this course, perceives it, smells it (the changing odors of growth and ripening), sees it. Such time is fleshed-out, irreversible (within the limits of the cycle), realistic. (208)

One negative feature of folkloric time, as Bakhtin holds, is cyclicity as it limits time since "time's forward impulse is limited by the cycle" (210). The folkloric form of time, which can be seen as "the basis for possible narratives (and narrative matrices)" 
(214), passes by fundamental changes marked by the emergence of the individual life and the subsequent weakness in the links of the ancient motifs to the life of nature.

When the immanent unity of time disintegrated, when individual life-sequences were separated out, lives in which the gross realities of communal life had become merely petty private matters; when collective labor and the struggle with nature had ceased to be the only arena for man's encounter with nature and the world - then nature itself ceased to be a living participant in the events of life. Then nature became, by and large, a "setting for action", its backdrop; it was turned into the landscape (217).

The ancient matrices, however, are preserved by virtue of the insistence of the folklore and language on maintaining a relation to the world, which can be traced in literature. Moreover, the ancient matrices are preserved in the idyll "in sublimated form"; however, "one or another element is partially or entirely omitted; or, common everyday life is not always thoroughly transformed-especially in the realistic idylls of recent times (nineteenth century)" (227-228).

When all is said, it should be highlighted that "art and literature are shot through with chronotopic values of varying degrees and scope. Each motif, each separate aspect of artistic work bears value" (Bakhtin 243). Time/space defines what can happen and who can act. Simultaneous existence of the phenomenon in literature appears in different periods of time. A place connects time and space. The representational significance of the chronotope is that it is the concretizing representation of time as it is the basic means to materialize time in space. "Time becomes, in effect, palpable and visible; the chronotope makes narrative events concrete, makes them take on flesh, causes blood to flow in their veins. An event can be communicated, it becomes information, one can give precise data on the place and time of its occurrence" (Bakhtin 250).

\section{Cloning humans and texts}

By cloning I mean getting an exact replica of the body/text, a replica that contains the most essential qualities, however, it does not represent the identity of such a body/text. Cloning binds layers of time with different spaces; an ancient text may be cloned in modern times and the cloned text may be reproduced into a third text via translation. The cloning of texts is similar to that of humans and many science fiction narratives represent this topic.

Cloning human bodies may not be accepted though some support it, listing a lot of benefits (Smith). Cloning human cells will result in tremendous therapeutic benefits, and, therefore, incurable and chronic diseases may be cured. In his article "Telling the Difference: Clones, Doubles and What's in Between" Amit Marcus explains the common opinion that a clone and a double can be used interchangeably to refer to the exact replica of "the original", a term he used to refer to a primary human being. To support this opinion, he quotes from Maria Alina Salgueiro Seabra Ferreira's book I Am the Other: Literary Negotiations of Human Cloning, published in 2005, in which she used the two terms interchangeably. Marcus differentiates between clones and doubles from a literary perspective: ""clone narratives" are science fiction narratives that feature clones as their main characters"; while "doubles narratives" are: "narratives in which one of the characters (usually the protagonist) believes that another character is a (usually false, deceptive, and inferior) copy of his self, or of part of his self, and this belief is supported by some textual evidence apart from the belief itself." Unlike the double, the concept of cloning is relatively new to science and literature. Developments in technology and science in this respect were reflected in concepts such as "copies, duplications and 
simulacra in contemporary culture, manifested in the works of Jean Baudrillard, Gilles Deleuze and Slavoj Žižek, among others" (Marcus). Human as well as fictional clones, as Marcus claims, are not the exact replica of the original. They can be made "copies" of the original through "conditioning and indoctrination rather than mere identical genes."

Many novels have been written on human cloning. The Human Cloning Foundation, a nonprofit organization, rated and reviewed these novels making a bookstore with aim of raising funds (Books about human cloning). The Bones of Time, written by Kathleen Ann Goonan and published in 1996, focuses on the good scientific intentions of cloning. The Klone and I, by Daniel Steele and published in 1998, discusses how a love relationship develops between Stephanie, Parker and his double, the Klone. The Boys from Brazil, written in 1976 by Ira Levin, highlights the possibility of having copies of such political leaders as Hitler. The 13-year-old clones from Hitler, created by Dr. Mengele, were to follow strictly Hitler's course of life; that is why their 65-year-old fathers were ordered to be killed in order to mimic Hitler's father's death. The scientific information of the process of cloning, provided by Levin, is inaccurate and misleading. Moreover, scientifically speaking, cloning disturbs "fundamental social categories" making us re-examine "meaning of parents, children, and sibling" (Wald \& Clayton).

\section{Never Let Me Go}

There is a strong relationship between art and the soul. "The capacity to produce art might prove that the cloned children have souls, and thus moral status" (Edgar). However, sometimes writers cannot express themselves clearly, thus, problematizing the link between the soul and art, Kazuo Ishiguro Never Let Me Go is an example. Kathy, Tommy and Ruth, clones, are convinced by a teacher's saying that one's art reflects his soul. The contradiction between the purpose of establishing Hailsham boarding school meant to give humane treatment for clones, and encouraging clones to produce art is soon to be revealed. Art, supposedly, a reflection of the clone's soul, is sold to raise funds after convincing people that clones have souls and special skills. The novel "employs the figure of the clone to demonstrate how the use of inherited narrative models in narrating the self, coupled with an education that upholds the value of a represented self over a physical self, encourages a distancing from the subjugated body" (Bloor 2). Here clones prove to have souls and have represented the self through re/producing art. The reproduced self/art will constantly connect with and be reinterpreted and assimilated through others' works through a chronotopic frame that blurs the author's identity.

\section{Reproduction of the human text/self (identity)}

By reproduction, I mean rewriting a text which, considered like a living being in this case, can express feelings in different situations, which shows an identity of its own based on the source identity. For a human body, it is difficult to realize this stage. The chronotope, time-space, controls the text. The text has sometimes been reproduced representing the same theme in the same place but in different times. For example, the theme of love versus duty was represented in Shakespeare's Antony \& Cleopatra (1623), at the reformation, and later in Dryden's All For Love (1677), representing neoclassicism. In All For Love the theme is cloned but the whole work is reproduced through the neoclassicist lens. In 1929, Ahmad Shawky wrote The Death of Cleopatra (Masra' Cleopatra), the theme was reshaped according to different temporal and spatial circumstances. Another example is the theme of family disintegration that was at the 
heart of Thomas Hardy's The Mayor of Casterbridge (1886); it was represented in Hassan Al Bindary's Consolation of the Soul (Salwa A Ruh) (2007). The theme of family disintegration is cloned but the whole work is reproduced through Jung's collective unconscious with cultural specifics marking a difference which may result in thousands of other texts based on different cultural contexts and different periods, and even within the same cultural context depending on Durkheim's collective consciousness.

\section{Universality of the theme and representational forces of time and space}

When the theme is universal, it is easily cloned. However, Chronotopic representation does differ from language to language and according to the passage of time. For examples, Sons and Lovers (1918) by D. H. Lawrence was cloned in The Mirage (A Sarab) (1948) by Naguib Mahfouz. The Mirage is a representation of the common topic in Sons and Lovers, viz., Oedipus Complex. Translation of Sons and Lovers in Arabic before the publication of The Mirage is a process of rendering a text from a language to another. With The Mirage in mind, a translator is dealing with a reproduction of the source, almost a second text. A third text is always lingering in the unknown making all interpretations and translations incomplete endeavors.

Sometimes, representation of ideas embraces either the concept of cloning or that of reproduction, stressing the possibility of infinite interpretations:

\section{Representation of ideas}

(Translating)

Translation as a reconstruction of memory

Source text

Cloned text $\quad$ (either cloned or reproduced) Reproduced text

A third text

(may be out of time or space control)

Translations of Shakespearean plays into Arabic come under either cloning or reproduction and sometimes under adaptation which is an ongoing process subject to the chronotopic representation, the temporal and spatial circumstances under which the text will be re/born. The adaptation of Shakespearean plays to the stage has been carried out through chronotopic representation which has had a formative impact on identity. Khalīl Muțān's translation of Othello in Standard Arabic and Mustapha Safouan's in the Egyptian vernacular (Hanna)hold good in this respect. Shakespeare's plays have transcended the temporal and spatial frame of the time of their publications, and have been translated, Arabized and Egyptianized many times (Awad 5-6), stressing the universality of the theme rather than the identity of the author.

The themes of hell, paradise and God's glory have passed from The Epistle of Forgiveness (first published in 1925) by Abū 1- 'Alā' al-Ma arrī (363-449 H/ 973-1057) to The Divine Comedy (written from 1308 to 1321 and published in 1472) by Dante Alighieri, (born c. May 21-June 20, 1265, Florence [Italy] - died September 13/14, 
1321, Ravenna) and have been crystallized in Paradise Lost (1667) and Paradise Regained (1671) by John Milton(1608-1674). Although the themes are universal, each work has its chronotopic representation. Various translations of these works and their like to the same or to different languages endorse the autonomy of the reproduced texts from the authorial sway as they are framed in the contemporary chronotopic within which they play.

\section{Conclusion}

Cloning of the text is similar to that of the human body; however, the text can be reproduced assuming a new identity unlike the human body. The nature of Bakhtin's chronotopic representation is tinctured with the image of the author as creator; however, Barthes' concluding statement that declares the author's demise allows reproduced texts to play freely and adapt to ever-evolving and revolving chronotopes. Therefore, the temporal and spatial frame within which texts go in a constant flux playing the role of both signifier and signified upon and thus creating identities of their own overshadowing that of the author highlights the inseparable wholeness of the concept of cloning and reproduction on the one hand and their chronotopic representation on the other. In this case, all texts are open to infinite interpretations, writings and translations, showing myriads of identities the fewest of which can safely be traced back to an original author.

\section{Works Cited}

A-Salem Abdullah. "Summary of the Epistle of Forgiveness: Abū 1- Alā' al-Ma 'arrî̀" (Mulakhs Risâlat al-ghufrân: Abū l- Alā' al-Ma'arrī ), Wosom, 28 Feb. 2018. https://wosom.net/blog/2008/02/28/\%D8\%B1\%D8\%B3\%D8\%A7\%D9\%84\% D8\%A9\%D8\%A7\%D9\%84\%D8\%BA\%D9\%81\%D8\%B1\%D8\%A7\%D9\%86/ Accessed 30 May 2021.

Awad, Ramsis. Shakespeare in Egypt (Shakespeare Fi Masr). Cairo: General Egyptian Book Organization, 1986.

Bakhtin, M. M. The Dialogic Imagination: Four Essays. Michael Holquist ed., Caryl Emerson and Michael Holquist trans., The University of Texas Press, 1981.

Barthes, Rolad "The Death of the Author", London: Fontana, 1977,pp 142-148 https://sites.tufts.edu/english292b/files/2012/01/Barthes-The-Death-of-theAuthor.pdf . Accessed 19 March 2021.

Bloor, Heather. Human Behaviour: An Exploration of Representation, Narrative, and the Clone Body in Kazuo Ishiguro's Never Let Me Go. Diss. Murdoch University, 2015.

Books about human cloning (fiction) reviewed by a member of the Human Cloning Foundation. http://www.humancloning.org/fiction.htm 1May, 2018.

Edgar, Andrew. "The Relationship Between Art and the Soul." Cardiff sciScreen. 23 March, 2011. http://cardiffsciscreen.blogspot.com/2011/03/relationshipbetween-art-and-soul-by.html 5 May, 2018.

Hanna, S. F. "Othello in Egypt: Translation and the (Un)making of National Identity." Translation and the Construction of Identity. Ed. House, J., Ruano, M. R. M., and Baumgarten, N. Seoul: International Association of Translation and Intercultural Studies, 2005. 109-28 
Marcus, Amit. "Telling the difference: clones, doubles and what's in between.

" Connotations: a Journal for Critical Debate, vol. 21, no.2/3, 2011, pp. 363-369.

Smith, Simon. "The Benefits of Human Cloning." Human Cloning Foundation. http://www.humancloning.org/benefits.html 11 June 2018.

Wald, P., \& Clayton, J. (2007). Editors' preface: Genomics in literature, visual arts, $\begin{array}{llll}\text { and culture. } & \text { Literature and }\end{array}$ VI,VII,VIII,IX,X,XI,XII,XIII,XIV,XV,XVI,277,279. Retrieved from https://library.iau.edu.sa/docview/221136705?accountid=136546 12 June, 2018.

\section{The Author}

\section{Prof. Yasser K. R. Aman}

Professor of English Literature, Department of English, College of Arts, Imam Abdulrahman Bin Faisal University, P.O. Box 1982, (Dammam 31441), Saudi Arabia.

Former Head of the English Department, Faculty of Al Alsun, Minia University, Egypt.

Email: yass712000@gmail.com

\section{The Article}

Date Sent: $29 / 12 / 2021$

Date Revised: 20/02/2022

Date Accepted: 20/02/2022 